\title{
Feeding associations between Guiana dolphins, Sotalia guianensis (Van Bénèden, 1864) and seabirds in the Lagamar estuary, Brazil
}

\author{
Santos, MCO.*, Oshima, JEF., Pacífico, ES. and Silva, E. \\ Projeto Atlantis, Laboratório de Biologia da Conservação de Cetáceos, Departamento de Zoologia, \\ Instituto de Biociências, Campus Rio Claro, \\ Universidade Estadual Paulista "Júlia de Mesquita Filho" - UNESP, \\ Av. 24-A, 1515, Bela Vista, Brazil, CEP 13506-900, Rio Claro, SP, Brazil \\ *e-mail: sotalia@gmail.com
}

Received June 6, 2008 - Accepted March 3, 2009 - Distributed February 28, 2009

(With 2 figures)

\begin{abstract}
The main objective of the present study was to describe the characteristics regarding interactions between Guiana dolphins, Sotalia guianensis and seabirds in feeding associations in two distinct areas of the Lagamar estuary, Brazil. Boat-based surveys directed towards photo-identification studies of S. guianensis were conducted in the Cananéia Estuary (CE) $\left(25^{\circ} 01^{\prime} \mathrm{S}\right.$ and $\left.47^{\circ} 55^{\prime} \mathrm{W}\right)$ from July 2004 to March 2008, as well as in the Paranaguá Estuarine Complex (PEC) $\left(25^{\circ} 24^{\prime} \mathrm{S}\right.$ and $\left.48^{\circ} 24^{\prime} \mathrm{W}\right)$ from April 2006 to February 2008. On all occasions when seabirds were observed engaging in multi-species feeding associations with $S$. guianensis, data on species involved and their numbers were gathered. From 435 observed groups of $S$. guianensis in the CE, $38(8.7 \%)$ involved interactions with seabirds. In the PEC, from the 286 observed groups, 32 (11.2\%) involved the mentioned interactions. The following seabirds were observed in feeding associations with S. guianensis: Fregata magnificens, Sula leucogaster, Phalacrocorax brasilianus, and Sterna sp. In the CE, S. leucogaster was more commonly observed in feeding associations with Guiana dolphins $\left(\chi^{2}=22.84\right.$; d.f. $\left.=3, \mathrm{p}<0.05\right)$, while in the PEC no differences were reported when comparing seabird species $\left(\chi^{2}=5.78\right.$; d.f. $\left.=3, \mathrm{p}=0.1223\right)$. In the $\mathrm{CE}$, feeding associations were significantly more frequent in inner waters (subset $\mathrm{A} 0 ; \chi^{2}=9.52$; d.f. $\left.=2, \mathrm{p}<0.05\right)$, and in winter $\left(\chi^{2}=12.46\right.$; d.f. $\left.=1, \mathrm{p}<0.05\right)$. Within these events, $44.7 \%$ of the association groups were composed by more than one seabird species. Seasonality in feeding associations was also observed in the PEC $\left(\chi^{2}=4.76\right.$; d.f. $\left.=1, \mathrm{p}<0.05\right)$, with same patterns observed in the CE. Interactions were more frequent in inner waters of the Laranjeiras bay, PEC $\left(\chi^{2}=11.65\right.$; d.f. $\left.=2, \mathrm{p}<0.05\right)$. Within these events, $74.2 \%$ of the association groups were composed by more than one seabird species. Water transparency, prey and seabird abundance and distribution, cetacean group size, and the life cycle of prey and seabirds are listed as the main factors addressing multi-species feeding associations in the Lagamar estuary.
\end{abstract}

Keywords: Cetacea, feeding associations, Sotalia guianensis, seabirds, multi-species interactions.

\section{Associações de alimentação entre o boto-cinza \\ (Sotalia guianensis) (Van Bénèden, 1864) e aves marinhas no estuário do Lagamar, Brasil}

\begin{abstract}
Resumo
O objetivo principal do presente estudo foi de descrever as características a respeito das associações de alimentação entre o boto-cinza, Sotalia guianensis, e aves marinhas em duas áreas distintas do estuário do Lagamar, Brasil. Investigações efetuadas a partir de embarcação e direcionadas a estudos de foto-identificação de $S$. guianensis foram conduzidas

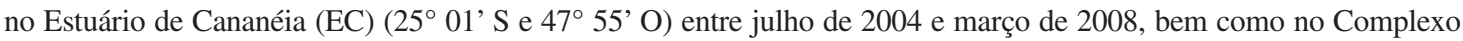
Estuarino de Paranaguá (CEP) (2524' S e 48 24' O) entre abril de 2006 e fevereiro de 2008. Em todas as ocasiões em que aves marinhas foram observadas em associações de alimentação multiespecífica com $S$. guianensis, dados sobre as espécies envolvidas e seus números foram obtidos. Dos 435 grupos de S. guianensis observados no EC, 38 (8,7\%) envolveram interações com aves marinhas. No CEP, dos 286 grupos observados, $32(11,2 \%)$ envolveram as interações mencionadas. As seguintes aves marinhas foram observadas em associações de alimentação com S. guianensis: Fregata magnificens, Sula leucogaster, Phalacrocorax brasilianus, Sterna sp. No EC, S. leucogaster foi significativamente mais observada em associação de alimentação com o boto-cinza $\left(\chi^{2}=22,84\right.$; g.l. $=3$ p < 0,05), enquanto no CEP não foram observadas diferenças quando comparadas as aves marinhas $\left(\chi^{2}=5,78\right.$; g.1. $\left.=3, \mathrm{p}=0,1223\right)$. No EC, associações de alimentação foram significativamente mais freqüentes em águas internas $\left(\chi^{2}=9,52\right.$; g.l. $\left.=2, \mathrm{p}<0,05\right)$ e no inverno
\end{abstract}


$\left(\chi^{2}=12,46 ;\right.$ g.l. $\left.=1, p<0,05\right)$. Dentre estes eventos, $44,7 \%$ dos grupos de associação foram compostos por mais de uma espécie. Sazonalidade nas associações de alimentação também foi observada no $\operatorname{CEP}\left(\chi^{2}=4,76 ;\right.$ g.l. $\left.=1, p<0,05\right)$, com os mesmos padrões observados para o EC. As interações foram mais freqüentes na baía das Laranjeiras, CEP $\left(\chi^{2}=\right.$ $11,65$; d.f. $=2, \mathrm{p}<0,05)$. Dentre estes eventos, $74,2 \%$ dos grupos de associação foram compostos por mais de uma espécie de ave marinha. A transparência da água, a distribuição e a abundância de presas e das aves marinhas, o tamanho de grupo dos cetáceos, e o ciclo de vida das aves marinhas e das presas são listados como os principais fatores que favorecem as associações de alimentação multiespecífica no estuário do Lagamar.

Palavras-chave: Cetacea, associações de alimentação, Sotalia guianensis, aves marinhas, interações multi-específicas.

\section{Introduction}

Associations between cetaceans and seabirds date back at least to the whaling activities of the $19^{\text {th }}$ century when whalers would use feeding seabirds as a cue to the presence of whales (e.g. Melville, 1851). These associations are widespread, occurring among several genera of both groups (e.g. Evans, 1982; Ridoux, 1987; Au, 1991; Bräger, 1998; Vaughn et al., 2007). Most associations, however, are probably opportunistic or incidental, as a result of concentration of shared prey. Evolutionary advantages of associating are likely to benefit seabirds rather than cetaceans (Evans, 1982; Vaughn et al., 2008). Although seabirds may compete among themselves and with predatory marine mammals and fish for the same prey, they clearly derive advantages including access to fish school detection from above and fish school compaction provided by aquatic predators (Ibid.). However, when travelling widely across oceans, seabirds may be only sporadic members of particular assemblages, and thus their effective competition may be intermittent (Burger, 1988). Pierotti (1988) proposed five possible forms of association between marine mammals and seabirds: (A) birds and mammals in same area, but exploiting different food types and not interacting, (B) birds and mammals attracted to the same food source, but not interacting, (C) birds actively attracted to foraging mammals, (D) birds feeding on by-products of mammals, i.e., feces and scraps of food, and (E) mammals preying on birds.

Interactions between cetaceans and seabirds have been observed worldwide (e.g. Würsig and Würsig, 1979; Würsig and Würsig, 1980; Evans, 1982; Au and Pitman, 1986; Shane, 1990; Neumann and Orams, 2003; Siciliano et al., 2004; Vaughn et al., 2007). In Brazil, most reports have involved associations between Guiana dolphins, Sotalia guianensis (Van Bénèden, 1864), and seabirds (e.g. Monteiro-Filho, 1992; Lodi and Hetzel, 2000; Cremer et al., 2004; Domit, 2006; Santos and Rosso, 2007). S. guianensis is commonly found in coastal and estuarine waters of South and Central America in the Western Atlantic Ocean (Flores, 2002), which makes the species the main target for observations of such interactions in Brazilian waters. One of the best known populations of S. guianensis dwells in the Lagamar estuary, which includes inshore waters from Iguape $\left(24^{\circ} 36^{\prime} \mathrm{S}\right.$ and $47^{\circ} 23^{\prime} \mathrm{W}$ ), São Paulo State, to Pontal do Sul $\left(25^{\circ} 36^{\prime} \mathrm{S}\right.$ and $\left.48^{\circ} 25^{\prime} \mathrm{W}\right)$, Paraná State. The whole area is surrounded by large mangrove forests with relatively turbid waters containing high concentrations of nutrients and fish found year-round (Besnard, 1950; Brandini,

1985; Schaeffer-Novelli et al., 1990; Mendonça and Katsuragawa, 1997; Corrêa, 2000). Due to their ecological importance, several areas of the Lagamar estuary were designated as protected reserves in the 1980s (see Schaeffer-Novelli et al., 1990; IPARDES, 2001). Thus, understanding the dynamics involving the food chain is an important tool for the management and conservation of these reserves. The way seabirds associate with dolphins is closely related to foraging tactics displayed by the latter (Evans, 1982). Seabirds benefit from feeding with cetaceans when they feed near the surface (Bräger, 1998; Ridoux, 1987; Vaughn et al., 2008). Thus, when evaluating the nature of such interactions, the characteristics of several environmental variables must be evaluated through time and space. Therefore, the main objective of the present study was to describe the characteristics of the feeding associations between $S$. guianensis and seabirds observed in the Lagamar estuary. Two previous studies conducted in two distinct areas of the same estuary listed several seabird species, as well as described several aspects of such associations (Monteiro-Filho, 1992; Domit, 2006). However, both studies gathered data from land platforms in restricted subsets of the estuary. In the present study, a broader area was covered through boat-based observations in order to investigate the possible influence of environmental characteristics on the evaluated multi-species associations.

\section{Material and Methods}

\subsection{Study Area}

This study took place in two different sub-areas of the Lagamar estuary: the Cananéia Estuary (CE) $\left(25^{\circ} 01^{\prime} \mathrm{S}\right.$ and $47^{\circ} 55^{\prime}$ W) sensu Schaeffer-Novelli et al. (1990), and the Paranaguá Estuarine Complex (PEC) (25 24' S and $48^{\circ} 24^{\prime}$ W) sensu Noernberg et al. (2006) (see Figure 1). The CE is located on the southern coast of São Paulo State and the surveyed area included the waters encircling the Cananéia island, as well as approximately $12 \mathrm{~km}$ northwards. The surveyed area had approximately $132 \mathrm{~km}^{2}$ divided into three smaller subsets known as A0, A1-A4, and A5 (see Figure 1). The PEC is located in the northeast portion of Paraná state and the surveyed area had approximately $124 \mathrm{~km}^{2}$ including the following subsets: Canal do Superagui, Pinheiros Bay, part of Laranjeiras Bay, which 


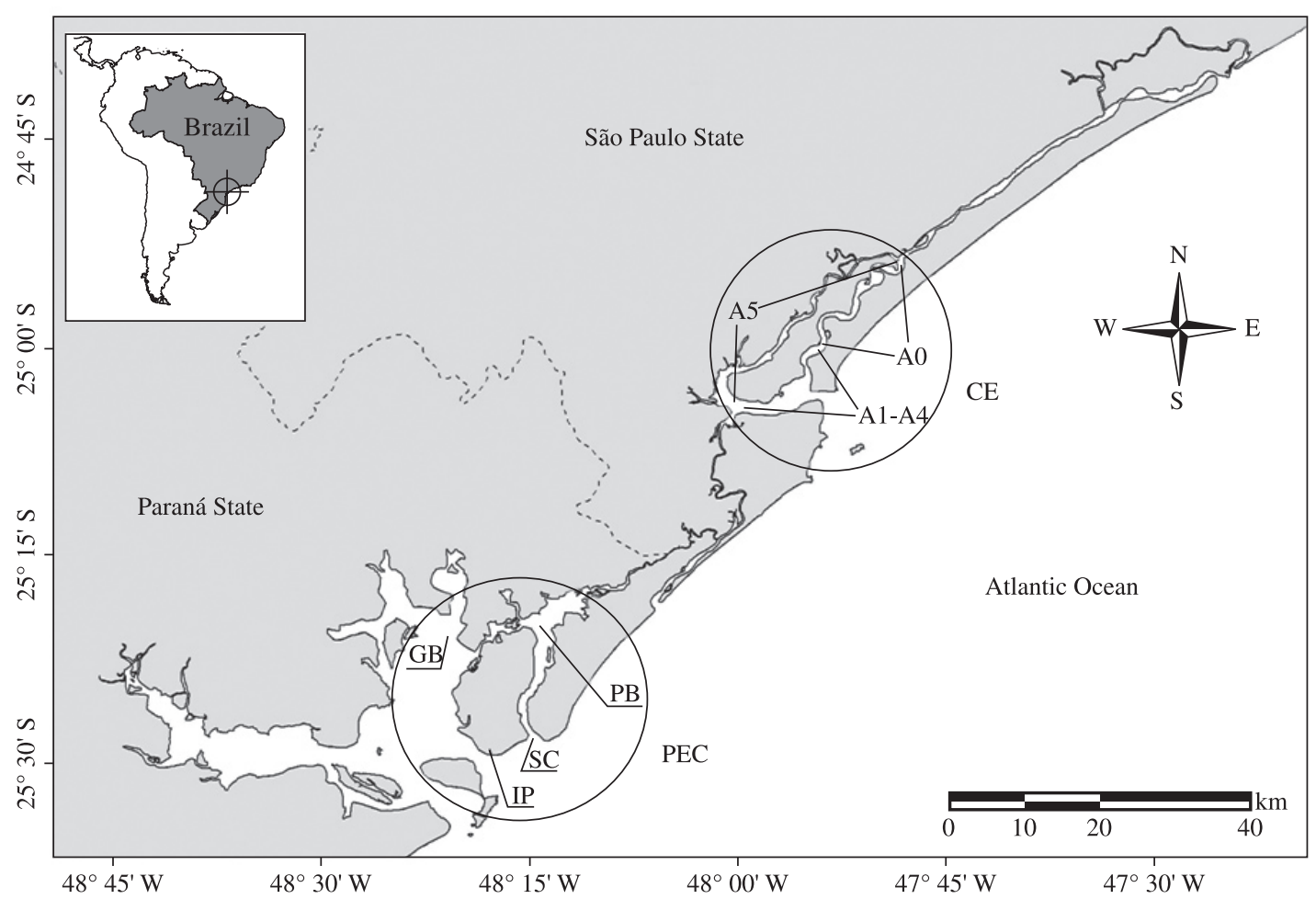

Figure 1. The Lagamar estuary highlighting the surveyed subsets in the Cananéia Estuary (CE) and in the Paranaguá Estuarine Complex (PEC) where the associations between Guiana dolphins (Sotalia guianensis) and seabirds were investigated from 2004 to 2008. GB = Laranjeiras Bay, PB = Pinheiros Bay, SC: Superagui Channel, IP = Ilha das Peças.

included the Guaraqueçaba sub-estuary, and part of the Mixture Section close to Ilha das Peças (see Figure 1).

\subsection{Data collection}

Fieldwork was conducted as part of a long-term investigation on the ecology of S. guianensis in the Lagamar estuary, which started in the 1990s in the CE (see Santos et al., 2001; Santos and Rosso, 2007; Santos and Rosso, 2008). From April 2006, the southern portion of the quoted estuary represented by the PEC has been surveyed to address further investigations on S. guianensis ecology. Basically, fieldwork has been conducted through boat-based observations using the photo-identification technique to monitor individually recognizable dolphins through time and space (Würsig and Würsig, 1977). A detailed description on the way the fieldwork has been conducted can be found in Santos and Rosso (2007).

For the present study, data regarding the observations in the CE were collected from July 2004 to March 2008, and from April 2006 to February 2008 in the PEC. Seasons when field efforts were conducted in each sub-area are shown in Tables 1 and 2. Seasons were divided as follows: summer (December-February), fall (March-May), winter (June-August), and spring (September-November). Usually, boat-based observations lasted from 8 to 12 days in each season, covering the whole subsets in each bigger area on at least three different occasions. When seabirds were observed engaging in multi-species feeding associa- tions with $S$. guianensis, data on species and their numbers were gathered. The latter were gathered from the winter of 2005 on in the CE, and from the autumn of 2006 on in the PEC. Seabirds were defined as associating with dolphins when they were observed within $10 \mathrm{~m}$ from the latter when engaged in feeding bouts. Based on the difficulties posed by the identification of terns from a distance, these seabirds were kept into the genus level. The following data on environmental characteristics were collected for all observed $S$. guianensis groups: water salinity (handheld refractometer), transparency (Secchi disk), and temperature at the surface (alcohol thermometer). Santos and Rosso (2007) presented the environmental characteristics for the $\mathrm{CE}$ and the data collected for the PEC are shown in this study.

\subsection{Data analysis}

Collected data were plotted to evaluate which seabird species associated more frequently with $S$. guianensis, as well as for comparisons in frequencies of association between seasons and/or subsets. The null hypotheses to be tested were:

- There were no differences in the frequencies of association among each species of seabirds and S. guianensis in feeding associations;

- There were no differences in the number of multispecies feeding association events between summer and winter, when most part of the fieldwork was conducted; and 
Table 1. Number of observed groups of Guiana dolphins (Sotalia guianensis) in 10 distinct seasons from 2004 to 2008 in the Cananéia Estuary. The number of groups reported in multi-species associations is presented, as well as the frequency of observation of each seabird.

\begin{tabular}{cccccccccccc}
\hline $\begin{array}{c}\text { Groups; } \\
\text { Seabirds/ } \\
\text { Seasons }\end{array}$ & $\begin{array}{c}\text { Winter } \\
\mathbf{2 0 0 4}\end{array}$ & $\begin{array}{c}\text { Spring } \\
\mathbf{2 0 0 4}\end{array}$ & $\begin{array}{c}\text { Summer } \\
\mathbf{2 0 0 5}\end{array}$ & $\begin{array}{c}\text { Winter } \\
\mathbf{2 0 0 5}\end{array}$ & $\begin{array}{c}\text { Summer } \\
\mathbf{2 0 0 6}\end{array}$ & $\begin{array}{c}\text { Winter } \\
\mathbf{2 0 0 6}\end{array}$ & $\begin{array}{c}\text { Summer } \\
\mathbf{2 0 0 7}\end{array}$ & $\begin{array}{c}\text { Winter } \\
\mathbf{2 0 0 7}\end{array}$ & $\begin{array}{c}\text { Spring } \\
\mathbf{2 0 0 7}\end{array}$ & $\begin{array}{c}\text { Summer } \\
\mathbf{2 0 0 8}\end{array}$ & Total \\
\hline $\begin{array}{c}\text { S. guianensis } \\
\text { (overall) }\end{array}$ & 63 & 29 & 17 & 57 & 29 & 39 & 61 & 63 & 21 & 56 & 435 \\
$\begin{array}{c}\text { S. guianensis } \\
\text { Seabird associations }\end{array}$ & 6 & 1 & 1 & 14 & 2 & 4 & 1 & 4 & 2 & 3 & 38 \\
$\quad \begin{array}{c}\text { Fregata } \\
\text { magnificens }\end{array}$ & 4 & - & 1 & 4 & 1 & - & - & 2 & - & 2 & 14 \\
$\quad \begin{array}{c}\text { Sula } \\
\text { leucogaster }\end{array}$ & 5 & 1 & 1 & 13 & 2 & 4 & 1 & 4 & 2 & - & 33 \\
$\begin{array}{c}\text { Phalacrocorax } \\
\text { brasilianus }\end{array}$ & 2 & - & - & 2 & 1 & 1 & 1 & 2 & - & 1 & 10 \\
$\quad$ Sterna sp. & 2 & - & 1 & 3 & 1 & 2 & - & - & - & - & 9 \\
\hline
\end{tabular}

Table 2. Number of observed groups of Guiana dolphins (Sotalia guianensis) in 6 distinct seasons from 2006 to 2008 in the Paranaguá Estuarine Complex. The number of groups reported in multi-species associations is presented, as well as the frequency of observation of each seabird.

\begin{tabular}{cccccccc}
\hline $\begin{array}{c}\text { Groups; Seabirds/ } \\
\text { Season }\end{array}$ & $\begin{array}{c}\text { Autumn } \\
\mathbf{2 0 0 6}\end{array}$ & $\begin{array}{c}\text { Winter } \\
\mathbf{2 0 0 6}\end{array}$ & $\begin{array}{c}\text { Spring } \\
\mathbf{2 0 0 6}\end{array}$ & $\begin{array}{c}\text { Summer } \\
\mathbf{2 0 0 7}\end{array}$ & $\begin{array}{c}\text { Winter } \\
\mathbf{2 0 0 7}\end{array}$ & $\begin{array}{c}\text { Summer } \\
\mathbf{2 0 0 8}\end{array}$ & Total \\
\hline $\begin{array}{c}\text { S. guianensis } \\
\text { (overall) }\end{array}$ & 39 & 43 & 33 & 46 & 53 & 72 & 286 \\
$\begin{array}{c}\text { S. guianensis } \\
\text { Seabird associations }\end{array}$ & 6 & 12 & 6 & 4 & 4 & - & 32 \\
$\quad \begin{array}{c}\text { Fregata } \\
\text { magnificens }\end{array}$ & 5 & 7 & 6 & 4 & 4 & - & 26 \\
$\quad \begin{array}{l}\text { Sula } \\
\text { leucogaster }\end{array}$ & 5 & 3 & 5 & 3 & 3 & - & 19 \\
$\begin{array}{c}\text { Phalacrocorax } \\
\text { brasilianus }\end{array}$ & 2 & 6 & 2 & 4 & 2 & - & 16 \\
$\quad$ Sterna sp. & 3 & 7 & - & - & 1 & - & 11 \\
\hline
\end{tabular}

- And there were no differences in the number of multi-species feeding association events among subsets. The analyses were conducted for the CE and the PEC separately.

Seasonal investigations for the CE were supported by the previously collected environmental data (see Santos and Rosso, 2007) and data collected in the present study supported the analyses for the PEC. The chi-square test was performed for these investigations (Zar, 1996) using the software STATISTICA FOR WINDOWS ${ }^{\circledR}$ 5.0 (StatSoft, Inc., Tulsa, OK, USA). Non-parametric statistics were used to analyse the environmental data because distributions were not normal. The 5\% significance level was adopted for all tests.

\section{Results}

From 435 observed groups of $S$. guianensis in the CE, $38(8.7 \%)$ involved interactions with seabirds (as shown in Table 1). In the PEC, from 286 observed groups, $32(11.2 \%)$ involved the quoted interactions (as shown in Table 2). The following seabirds were observed in feeding associations with $S$. guianensis: frigatebird, Fregata magnificens (Matheus, 1914); brown boobie, Sula leucogaster (Boddaert, 1783); Neotropic cormorant, Phalacrocorax brasilianus (Gmelin, 1789); and tern, Sterna sp. Numbers (mean; SD, variation) of seabirds engaged in feeding associations with Guiana dolphins are shown in Table 3. In the CE, brown boobies were more commonly observed in feeding associations with $S$. guianensis $\left(\chi^{2}=22.84\right.$; d.f. $=3$; $\mathrm{p}<0.05$;), while in the PEC, although $F$. magnificens was observed in $80.6 \%$ of the association groups, no significant differences were observed when comparing different seabirds $\left(\chi^{2}=5.78\right.$; d.f. $\left.=3 ; \mathrm{p}=0.1223\right)$. In the $\mathrm{CE}$, feeding associations were significantly more frequent in subset A0 $\left(\chi^{2}=9.52 ;\right.$ d.f. $\left.=2 ; \mathrm{p}<0.05\right)$ and in winter $\left(\chi^{2}=\right.$ 12.46; d.f. $=1 ; \mathrm{p}<0.05)$. Within these events, $44.7 \%$ of the association groups were composed of more than one 
Table 3. Numbers (mean, SD, $\mathrm{N}$ of groups, and variation) of seabirds observed in multi-species associations with Guiana dolphins (Sotalia guianensis) in the Cananéia Estuary (from the winter of 2005 on) and in the Paranaguá Estuarine Complex (from the autumn of 2006 on).

\begin{tabular}{lcccccc}
\hline \multicolumn{1}{c}{ Seabirds/Subarea } & \multicolumn{3}{c}{ Cananéia estuary } & \multicolumn{2}{c}{ Paranaguá estuarine complex } \\
\hline & Mean \pm SD & N & Variation & Mean \pm SD & N & Variation \\
\hline Fregata magnificens & $10.3 \pm 15.4$ & 9 & 1 to 40 & $11.1 \pm 9.9$ & 26 & 1 to 40 \\
Sula leucogaster & $18.6 \pm 20.8$ & 26 & 1 to 70 & $17.0 \pm 18.6$ & 19 & 1 to 70 \\
Phalacrocorax brasilianus & $7.3 \pm 6.1$ & 8 & 1 to 15 & $22.3 \pm 23.7$ & 16 & 1 to 100 \\
Sterna sp. & $3.5 \pm 3.3$ & 6 & 1 to 10 & $5.2 \pm 5.2$ & 11 & 1 to 20 \\
\hline
\end{tabular}

Table 4. Group size and composition of Guiana dolphins (Sotalia guianensis) observed in four sub-areas of the Paranaguá Estuarine Complex from April 2006 to February 2008. SD = Standard Deviation, Nbs = Newborns.

\begin{tabular}{lccccccc}
\hline \multicolumn{1}{c}{ Sub-areas } & \# Groups & Mean \pm SD & Variation & \# Adults & \# Calves & \# Nbs & \% Nbs \\
\hline Canal & 87 & $5.3 \pm 3.6$ & 1 to 20 & 314 & 143 & 17 & 12 \\
Pinheiros & 81 & $12.7 \pm 17.1$ & 1 to 80 & 656 & 273 & 61 & 22 \\
Laranjeiras & 98 & $14.2 \pm 15.2$ & 2 to 90 & 902 & 409 & 37 & 9 \\
Peças & 20 & $23.3 \pm 19.2$ & 5 to 80 & 213 & 104 & 10 & 10 \\
Overall & 286 & $11.5 \pm 14.4$ & 1 to 90 & 2085 & 929 & 125 & 13 \\
\hline
\end{tabular}

$\#=$ number of

seabird species. Seasonality in feeding associations was also observed in the PEC $\left(\chi^{2}=4.76\right.$; d.f. $\left.=1 ; \mathrm{p}<0.05\right)$, with same patterns observed in the $\mathrm{CE}$. Interactions were more frequent in the Laranjeiras bay $\left(\chi^{2}=11.65\right.$; d.f. $=3$; $\mathrm{p}<0.05)$. Within these events, $74.2 \%$ of the association groups were composed by more than one seabird species. When comparing the average number of seabirds engaging in multispecies associations with Guiana dolphins in both areas, the same patterns were observed, except for $P$. brasilianus (see Table 3 ). In the PEC their numbers were clearly larger when compared to the $\mathrm{CE}$.

Guiana dolphin groups varied from two individuals to aggregations of up to 90 individuals in the PEC (Table 4). Group size varied significantly among sub-areas (Kruskal Wallis, $\mathrm{H}_{2,196}=29.85, p=0.0000$ ). Groups were larger in Laranjeiras bay and smaller in Canal do Superagui. In the CE, groups were larger in the main estuary entrance (see Santos and Rosso, 2007).

The water temperature in the PEC varied from 15 to $31{ }^{\circ} \mathrm{C}$, with an expected significant difference observed when comparing summer (mean $\pm \mathrm{SD}=27.4 \pm 1.1^{\circ} \mathrm{C}$, $\mathrm{n}=121)$ and winter $\left(\right.$ mean $\left.\pm \mathrm{SD}=17.2 \pm 1.1^{\circ} \mathrm{C}, \mathrm{n}=100\right)$ after joining data from all the subsets together (Mann Whitney, $U=12.09$; $p=0.0000)$. Differences were reported when comparing salinity values among subsets joining both seasons (Kruskal Wallis, $\mathrm{H}_{3,226}=43.52$, $\mathrm{p}=0.0000$ ). To address a more detailed investigation, Mann Whitney tests were performed to compare salinity values between seasons in each of the main surveyed subsets with the following results: Canal, $U=87.50$, $\mathrm{p}=0.0000 ;$ Pinheiros, $\mathrm{U}=117.50, \mathrm{p}=0.0000$; and Laranjeiras, $\mathrm{U}=64.50, \mathrm{p}=0.0000$. As a general result, lower salinity values were usually found in inner waters in summer. The water transparency varied from 0.4 to
$3.8 \mathrm{~m}$. Differences were reported when comparing water transparency values among subsets joining both seasons (Kruskal Wallis, $\mathrm{H}_{2,206}=29.33, \mathrm{p}=0.0000$ ). To address a more detailed investigation, Mann Whitney tests were performed to compare transparency values between seasons in each of the surveyed subsets with the following results: Canal, $\mathrm{U}=58.00, \mathrm{p}=0.0000$; Pinheiros, $\mathrm{U}=54.50, \mathrm{p}=0.0000$; and Laranjeiras, $\mathrm{U}=260.00$, $\mathrm{p}=0.0000$. As a general result, the water was darker in inner waters in summer.

\section{Discussion}

Although the observed number of multi-species feeding association groups involving seabirds and S. guianensis can be considered relatively small (9.6\% of all observed groups), it was possible to gather interesting information on those interactions. Through boat-based surveys, it was possible to investigate a relatively large area of approximately $256 \mathrm{~km}^{2}$ and report a few spatial differences on the frequency of feeding associations between $S$. guianensis and seabirds. On the other hand, the same patterns of associations between dolphins and seabirds were observed in both surveyed areas. Feeding associations were more common in winter in both areas of the Lagamar estuary (CE and PEC), when the water is clear (see Santos and Rosso, 2007). Therefore, our results showed that water transparency is likely to be one of the factors influencing prey capture by seabirds when associating with dolphins. In the rainy summer season, organic matter is carried from the huge chain of mountains and mangrove forests found in close proximity to the inner areas of the estuary, turning darker the local waters. In the dry winter season it is common to ob- 
serve clearer waters (see Maciel, 2001; Santos \& Rosso, 2007). Water clarity was also indicated as an important variable to influence the seabirds associations with dusky dolphins Lagenorhynchus obscurus (Gray, 1828) in Admiralty bay, New Zealand (Vaughn et al., 2008), where the mean water clarity was $10 \mathrm{~m}$. As seabirds perform their captures close to the water surface, detecting prey is easier in clear rather than in dark waters.

The observed seabirds in the present study were previously described in interactions with $S$. guianensis (e.g. Monteiro-Filho, 1992; Lodi and Hetzel, 2000; Cremer et al., 2004; Domit, 2006; Santos and Rosso, 2007) and they have different foraging tactics. Our observations were similar to the ones described in the literature. S. leucogaster and Sterna spp. can be described as "surface plungers" as they can reach the prey only in the uppermost volume of water closest to the surface (see Ashmole, 1971). "Pursuit divers" like P. brasilianus search for food while swimming with their eyes below the water surface and dive after a detected prey (Ibid.). F. magnificens capture fish at the water surface (see Figures 2a, b), but not plunging into the water. They also chase and steal prey from other birds in the air (terns and brown boobies mostly). This typical behaviour can be called piracy sensu Diamond (1973). In winter, brown boobies usually followed Guiana dolphins after the latter started to display foraging and feeding activities. Boobies used to remain on the water surface close to dolphin aggregations, just waiting for the feeding bouts conducted by the latter, which could represent the indication that fish was aggregated and available. Cormorants sometimes displayed the same approach, but, however, they used to fly to localities where dolphins were feeding and periodically stuck their heads underwater, probably to locate prey. Frigate birds got captured prey from Sterna sp. and S. leucogaster on several occasions, as well as small fish on the water surface. Terns also adopted this last strategy.

Some delphinids change feeding strategies intraannually, often owing to changing prey abundance or distribution (Gaskin, 1968; Evans, 1971; Nichol and
Shackleton, 1996). Delphinid feeding tactics help to determine other predator associations during feeding bouts (Würsig and Würsig, 1980; Evans, 1982; Bräger, 1998) and an examination of dolphin and other predator relationships may lead to a better understanding of the interactions between them (Vaughn et al., 2007). Dusky dolphins were reported feeding in two distinct areas in different seasons in New Zealand, shifting prey type and daily activity patterns via diverse feeding tactics in different habitats (McFadden, 2003). These strategies demonstrated considerable behavioural plasticity imposed by habitat and prey items. The same plasticity in feeding strategies displayed by $S$. guianensis was previously observed in the CE (see Santos et al., 2002, Santos and Rosso, 2007) where seasonal changes in prey species abundance are known to occur (see Corrêa, 2000; Maciel, 2001). Bottom-dwelling Sciaenid fish are known to be one of the main prey items of $S$. guianensis in the CE (Santos et al., 2002). In tropical and subtropical estuarine systems, Sciaenid fishes are dominant (Blaber, 2002) and, as an opportunistic feeder, S. guianensis takes advantage of such abundance. When foraging in the bottom in shallow waters, $S$. guianensis may force prey to escape to waters closer to the surface, where it will be attainable by other predators such as seabirds. In other areas where water clarity provided conditions for underwater observations, dolphins increased prey accessibility for seabirds by decreasing depth and mobility of prey (see Vaughn et al., 2008), a phenomenon that was previously stated in such associations (see Ashmole, 1968; Evans, 1982; Shealer, 2002; Bugoni and Vooren, 2004). On the other hand, S. guianensis was witnessed preying on sardines Sardinella brasiliensis, (Steindachner, 1879), Clupeidae in three consecutive winter seasons in the subset A0 of the CE (Santos and Rosso, 2007). Zanelatto (2001) observed that one of the most representative species in the diet of $S$. guianensis in the PEC in winter was another sardine fish from the Clupeidae family: Pellona harroweri (Fowler, 1917). Sardines can be found in large schools usually close to the water surface and part of their life cycles depends on estuarine ar-
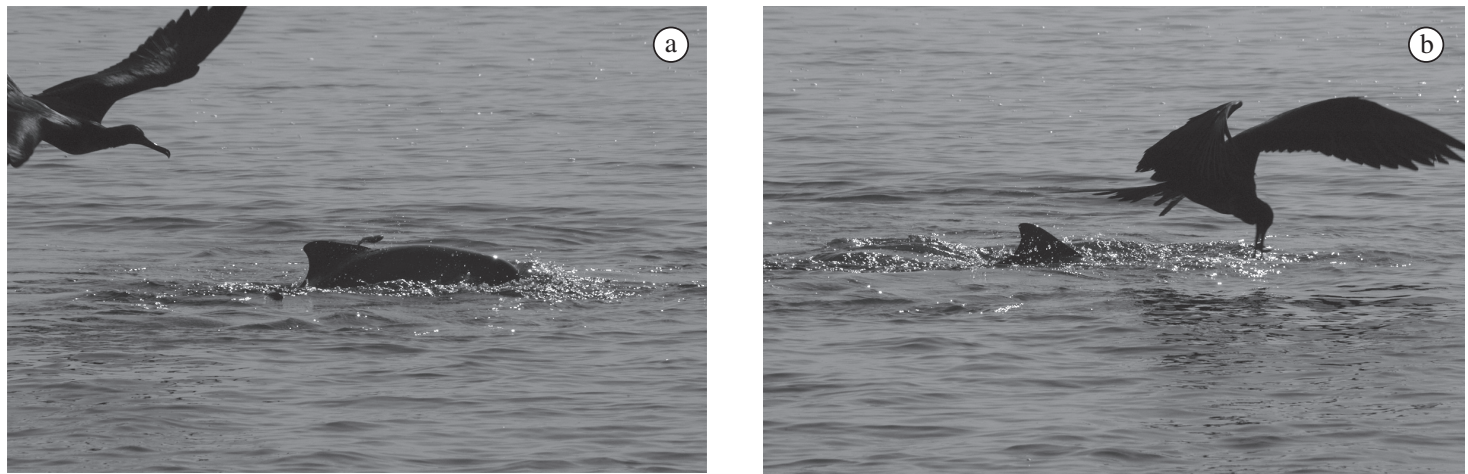

Figure 2. Frigate bird (Fregata magnificens) capturing a fish close to the water surface during a fish bout displayed by a Guiana dolphin (Sotalia guianensis) in the Lagamar estuary. 
eas such as the Lagamar (see Richardson and Sadowsky, 1960; Rossi-Wongtschowski, 1977; Maciel, 2001). As a consequence, the abundance of prey, added to the water transparency, represent important factors driving the observations of seabird-dolphin feeding associations in the quoted estuary in winter. Unfortunately, the relatively turbid waters of the surveyed area compromise underwater observations, which could provide a detailed description of $S$. guianensis feeding strategies.

Detailed observations of feeding associations involving cetaceans and seabirds may identify ways in which one could derive benefit from the other (Evans, 1982). Although this was not the main objective of this study, it is important to point out that the most common type of association observed between seabirds and $S$. guianensis in the Lagamar estuary was similar to the type $\mathrm{C}$ sensu Pierotti (1988), in which seabirds are attracted to dolphins in feeding activities. This type of association was also the most commonly observed by Monteiro-Filho (1992) and Cremer et al. (2004). Evans (1982) stated that the majority of associations could simply be incidental and due to a common food resource. When considering seabirds and cetaceans, interactions usually occur where prey is available to one or both members. In the Lagamar estuary this seems to be true because the quoted predators are exploring the same resource. Several studies on seabird feeding habits in closer areas (see Krul, 2004; Branco et al., 2005; Barquete et al., 2008) showed that they feed on almost the same abundant estuarine fishes reported to be preyed by $S$. guianensis. The mean prey size observed for brown boobies, Neotropic cormorants and Guiana dolphins, ranging from 9 to $13 \mathrm{~cm}$ in length, were approximately the same (see Santos et al., 2002; Krul, 2004; Branco et al., 2005; Barquete et al., 2008). Therefore, based on the described scenario, S. guianensis aggregations engaged in foraging and feeding activities may act as visual sign to seabirds. Intensive feeding activity at the sea surface can provide a conspicuous visual cue to seabirds that feeding is taking place (Evans, 1982; Vaughn et al., 2008). In this case, larger groups of cetaceans would usually be promptly detected when compared to smaller ones. Feeding associations between $S$. guianensis and seabirds in the CE were more frequently observed in subsets where dolphin groups were usually large (see Santos and Rosso, 2007). The same tendency has been observed for the PEC (see Table 4 and Results). Therefore, $S$. guianensis group size is also likely to influence the observation of feeding associations with seabirds.

To better understand the nature of the associations between $S$. guianensis and seabirds in the Lagamar estuary, it is necessary to gather information about the life cycle, which includes migration, and abundance of seabirds. It is known that the peak of the reproductive season of the observed marine birds begins in autumn and ends in spring (see Sick, 1997; Campos et al., 2004). Considering all the observed species, only Sterna spp. are usually found in lower numbers in closer coastal is- lands (Campos et al., 2004). From at least three species of terns found in closer islands, Sterna hirundinacea (Lesson, 1831) is migratory and is usually absent in summer (Campos et al., 2004; Bugoni and Vooren, 2005). The remaining seabird species are found in larger numbers all year round (Campos et al., 2004; Krul, 2004). Thus, seabird abundance and distribution can also be listed as one of the main factors driving the interactions with Guiana dolphins into different degrees in the Lagamar estuary (see Tables 1 and 2). Closer to the PEC, the island named Ilha do Castilho represents an important breeding spot for F. magnificens and S. leucogaster (Campos et al., 2004). Their local abundance may have influenced the higher number of associations between frigatebirds and Guiana dolphins in the PEC. S. leucogaster is known to breed in at least 10 islands along the State of São Paulo, including Ilha do Castilho, but their numbers on this island were estimated at half of the numbers of $F$. magnificens (Ibid.). The Neotropic cormorant lives in both freshwater and marine environments (see Harrison, 1985), and they are abundant in local mangrove forests year-round. There is no information on their local abundance. However, cormorants were observed in higher numbers of individuals in feeding associations with Guiana dolphins in the PEC when compared to the other seabirds (see Table 3 ). In a highly productive estuary such as the Lagamar, which is surrounded by a large mangrove forest that can be used as nesting sites, it would be expected that a primarily generalist seabird species like the Neotropic cormorant (see Telfair and Morrison, 1995) would be found in large numbers. Their numbers were higher in the PEC when compared to the CE (see Table 3). Nevertheless, a survey on their local breeding sites and abundance could highlight the reasons that might be driving the observed differences.

Further studies on local seabirds feeding habits, distribution and abundance will certainly add new pieces to the puzzle regarding the ecological aspects that drives the feeding associations between $S$. guianensis and seabirds. For the moment, it is possible to conclude that water transparency, prey and seabird abundance and distribution, cetacean group size, and the life cycle of prey and seabirds are the main factors addressing multi-species feeding associations in the Lagamar estuary.

Acknowledgements - Fundação de Amparo à Pesquisa do Estado de São Paulo (FAPESP) provided grants through the "Young Researcher Programme" ("Programa Jovem Pesquisador" process 05/59439-5 and 05/54149-9). Financial support came also from the Earthwatch Institute, the Cetacean Society International, and the Whale and Dolphin Conservation Society. Support in the field was provided by the Instituto Oceanográfico da Universidade de São Paulo, as well as the Núcleo Pro-Ação, Guaraqueçaba - Pontifícia Universidade Católica do Paraná. Julia Oshima and Eduardo Pacífico received grants from the Agência Nacional do Petróleo (ANP), Financiadora de Estudos e Projetos (FINEP), Ministério da Ciência e Tecnologia (MCT), Programa de Recursos Humanos da ANP para o setor de petróleo e gás - PRH-ANP/MCT. Three anonymous referees made useful suggestions to improve the manuscript. 


\section{References}

ASHMOLE, NP., 1968. Body size, prey size, and ecological segregation in five sympatric terns (Aves: Laridae). Systematic Zoology, vol. 17, p. 292-304.

1971. Seabird ecology and the marine environment. In: FARNER, DS. and KING, JR. (Eds.). Avian Biology. Vol. 1. New York: Academic Press. p. 223-287.

AU, DWK., 1991. Polyspecific nature of tuna schools: shark, dolphins, and seabird associates. Fishery Bulletin, vol. 89, p. 227-267.

AU, DWK. and PITMAN, RL., 1986. Seabird associations with dolphins and tuna in the Eastern Tropical Pacific. The Condor, vol. 88 , p. $304-317$

BARQUETE, V., BUGONI, L. and VOOREN, CM., 2008. Diet of Neotropic cormorant (Phalacrocorax brasilianus) in an estuarine environment. Marine Biology, vol. 153, p. 431-443.

BESNARD, W., 1950. Considerações gerais em torno da região lagunar de Cananéia-Iguape. Boletim do Instituto Paulista de Oceanografia, vol. 1, p. 9-26.

BLABER, SJM., 2002. Fish in hot water: the challenges facing fish and fisheries research in tropical estuaries. Journal of Fish Biology, vol. 61, p. 1-20.

BRÄGER, S., 1998. Feeding associations between white-fronted terns and Hector's dolphins in New Zealand. The Condor, vol. 100 , p. 560-562.

BRANCO, JO., FRACASSO, HAA., MACHADO, IF., BOVENDORP, MS. and VERANI, JR., 2005. Dieta de Sula leucogaster Boddaert (Sulidae, Aves), nas Ilhas Moleques do Sul, Florianópolis, Santa Catarina, Brasil. Revista Brasileira de Zoologia, vol. 22, no. 4, p. 1044-1049.

BRANDINI, FP., 1985. Ecological studies in the Bay of Paranaguá. I- Horizontal distribution and seasonal dynamics of the phytoplancton. Boletim do Instituto Oceanográfico, vol. 33, p. 139-147.

BUGONI, L. and VOOREN, CM., 2004. Feeding ecology of the common tern Sterna hirundo in a wintering area in southern Brazil. Ibis, vol. 146, p. 438-453.

2005. Distribution and abundance of six tern species in southern Brazil. Waterbirds, vol. 28, no. 1, p. 110-119.

BURGER, J., 1988. Interactions of marine birds with other marine vertebrates in marine environments. In: BURGER, J. (Ed.). Seabirds and Other Marine Vertebrates: competition, predation and other interactions. New York: Columbia University Press. Chap.1, p. 3-28.

CAMPOS, FP., PALUDO, D., FARIA, PJ. and MARTUSCELLI, P., 2004. Aves insulares marinhas, residentes e migratórias, do litoral do Estado de São Paulo. In BRANCO, JO. (Ed.). Aves Marinhas e Insulares Brasileiras: bioecologia e conservação. Itajaí: Editora da Univali. Chap. 3, p. 57-70.

CORRÊA, MFM., 2000. Ictiofauna demersal da Baía de Guaraqueçaba (Paraná, Brasil). Composição, estrutura, distribuição espacial, variabilidade temporal e importância como recurso. Curitiba, PR: Setor de Ciências Biológicas, Universidade Federal do Paraná. 160 p. [Doctoral Thesis]

CREMER, MJ., SIMÕES-LOPES, PC. and PIRES, JSR., 2004. Interações entre aves marinhas e Sotalia guianensis (P.J. Van
Benéden, 1864) na Baía da Babitonga, sul do Brasil. Revista Brasileira de Zoociências, vol. 6, p. 103-114.

DIAMOND, AW., 1973. Notes on the breeding biology and behaviour of the magnificent frigatebird. The Condor, vol. 75, p. 200-209.

DOMIT, C., 2006. Comportamento de pesca do boto-cinza, Sotalia guianensis (van Bénéden, 1864). Curitiba, PR: Universidade Federal do Paraná. 86p. [Masters Dissertation]

EVANS, PGH., 1982. Associations between seabirds and cetaceans: a review. Mammal Review, vol. 12, p. 187-206.

EVANS, WE., 1971. Orientation behavior of delphinids: radio telemetric studies. Annals of the New York Academy of Sciences, vol. 188 , p. $142-160$

FLORES, PAC., 2002. Tucuxi (Sotalia fluviatilis). In PERRIN, WF., WÜRSIG, B. and THEWISSEN, JGM. (Eds.). Encyclopedia of Marine Mammals. San Diego, CA: Academic Press. p. 1267-1269.

GASKIN, DE., 1968. Distribution of delphinidae (Cetacea) in relation to sea surface temperatures off eastern and southern New Zealand. New Zealand Journal of Marine and Freshwater Research, vol. 2, p. 527-534.

HARRISON, P., 1985. Seabirds: an identification guide. Boston, USA: Houghton Mifflin.

INSTITUTO PARANAENSE DE DESENVOLVIMENTO ECONÔMICOESOCIAL-IPARDES, 1990.Macro-zoneamento da Área de Proteção Ambiental de Guaraqueçaba. Vol. I. $254 \mathrm{p}$.

KRUL, R., 2004. Aves marinhas costeiras do Paraná. In: BRANCO, JO. (Ed.). Aves marinhas e insulares brasileiras: bioecologia e conservação. Itajaí: Editora da Univali. Chap. 2, p. 37-56.

LODI, L. and HETZEL B., 2000. Cleptoparasitismo entre fragatas (Fregata magnificens) e botos-cinza (Sotalia fluviatilis) na Baía de Paraty, Rio de Janeiro, Brasil. Biociências, vol. 8, p. 59-64.

MACIEL, NAL., 2001. Composição, abundância e distribuição espaço-temporal da ictiofauna do complexo estuarino-lagunar de Cananéia, São Paulo, Brasil. São Paulo: Instituto Oceanográfico, Universidade de São Paulo. 252p. [Doctoral Thesis]

MCFADDEN, CJ., 2003. Behavioral flexibility of feeding dusky dolphins (Lagenorhynchus obscurus) in Admiralty bay, New Zealand. Texas, United States: Texas A\&M University. 129 p. [Masters Dissertation]

MELVILLE, H., 1851. The Whale. New York: Harper and Brothers and London: Richard Bentley.

MENDONÇA, JT. and KATSURAGAWA, M., 1997. Desembarque da pesca costeira em Cananéia, São Paulo, Brasil, durante 1995 e 1996. Nerítica, vol. 11, p. 165-190.

MONTEIRO-FILHO, ELA., 1992. Pesca associada entre golfinhos e aves marinhas. Revista Brasileira de Zoologia, vol. 9 , no. $1 / 2$, p. 29-37.

NEUMANN, DR. and ORAMS, MB., 2003. Feeding behaviours of short-beaked common dolphins, Delphinus delphis, in New Zealand. Aquatic Mammals, vol. 29, no. 1, p. 137-149. 
NICHOL, LM. and SHACKLETON, DM., 1996. Seasonal movements and foraging behavior of northern resident killer whales (Orcinus orca) in relation to the inshore distribution of salmon (Oncorhynchus spp.) in British Columbia. Canadian Journal of Zoology, vol. 74, p. 983-991.

NOERNBERG, MA., LAUTERT, LFC., ARAÚJO, AD., MARONE, E., ANGELOTTI, R., NETTO Jr., JPB. and KRUG, LA., 2006. Remote Sensing and GIS Integration for modelling the Paranaguá Estuarine Complex-Brazil. Journal of Coastal Research, vol. 39, p. 1627-1631.

PIEROTTI, R., 1988. Associations between marine birds and mammals in the northwest Atlantic Ocean. In BURGER, J. (Ed.). Seabirds and other marine vertebrates: competition, predation and other interactions. New York: Columbia University Press. Chap. 2, p. 31-58.

RICHARDSON, ID. and SADOWSKY, V., 1960. Note on the sampling of sardine (Sardinella allecia) at Cananéia, State of São Paulo, Brazil. Boletim do Instituto Paulista de Oceanografia, vol. 6, p. 87-97.

RIDOUX, V., 1987. Feeding association between seabirds and killer whales, Orcinus orca, around subantarctic Crozet Islands. Canadian Journal of Zoology, vol. 65, p. 2113-2115.

ROSSI-WONGTSCHOWSKI, CLDB., 1977. Estudo das variações da relação peso total/comprimento total em função do ciclo reprodutivo e comportamento de Sardinella brasiliensis (Steindachner, 1879) da costa do Brasil entre $23^{\circ} \mathrm{S}$ e $28^{\circ} \mathrm{S}$. Boletim do Instituto Oceanográfico, vol. 26, p. 131-180.

SANTOS, MC. de O., ACUÑA, LB. and ROSSO, S., 2001. Insights on site fidelity and calving intervals of the marine tucuxi dolphin (Sotalia fluviatilis) in south-eastern Brazil. Journal of the Marine Biological Association, vol. 81, p. 1049-1052.

SANTOS, MC. de O. and ROSSO, S., 2007. Ecological aspects of marine tucuxi dolphins (Sotalia guianensis) based on group size and composition in the Cananéia estuary, southeastern Brazil. Latin American Journal of Aquatic Mammals, vol. 6, p. 71-82.

2008. Social organization of marine tucuxi dolphins, Sotalia guianensis, in the Cananéia estuary of southeastern Brazil. Journal of Mammalogy, vol. 89, p. 347-355.

SANTOS, MC. de O., ROSSO, S., SANTOS, RA., LUCATO, SHB. and BASSOI, M., 2002. Insights on small cetacean feeding habits in southeastern Brazil. Aquatic Mammals, vol. 28 , p. $38-45$.

SCHAEFFER-NOVELLI, Y., MESQUITA, HSL. and CINTRÓN-MOLERO, G., 1990. The Cananéia lagoon estuarine system, São Paulo, Brazil. Estuaries, vol. 13, p.193-203.
SHANE, SH., 1990. Behavior and ecology of the bottlenose dolphin at Sanibel Island, Florida. In LEATHERWOOD, S. and REEVES, RR. (Eds.). The Bottlenose Dolphin. San Francisco: Academic Press. p. 245-265.

SHEALER, DA,. 2002. Foraging behavior and food of seabirds. In SCHREIBER, EA. and BURGER, J. (Eds.). Biology of Marine Birds. Boca Raton, Florida: CRC Press. p. 137-177.

SICILIANO, S., SANTOS, MC. de O., VICENTE, AFC., ALVARENGA, FS., ZAMPIROLLI, E., BRITO Jr, JL., AZEVEDO, AF. and PIZZORNO, JLA., 2004. Strandings and feeding records of Bryde's whales (Balaenoptera edeni) in south-eastern Brazil. Latin American Journal of Aquatic Mammals, vol. 84, p. 857-859.

SICK, H., 1997. Ornitologia Brasileira. Rio de Janeiro: Nova Fronteira.

TELFAIR, RC II. and MORRISON, ML., 1995. Neotropic cormorant (Phalacrocorax brasilianus). In POOLE, A. and GILL, F. (Eds). The birds of North America. Washington, DC, USA: The Academy of Natural Sciences. Chap. 137, p. 1-22.

VAUGHN, RL., SHELTON, DS., TIMM, LL., WATSON, LA. and WÜRSIG, B., 2007. Dusky dolphin (Lagenorhynchus obscurus) feeding tactics and multi-species associations. New Zealand Journal of Marine and Freshwater Research, vol. 41, p. $391-400$

VAUGHN, RL., WÜRSIG, B., SHELTON, DS., TIMM, LL. and WATSON, LA., 2008. Dusky dolphins (Lagenorhynchus obscurus) influence prey accessibility for seabirds in Admiralty bay, New Zealand. Journal of Mammalogy, vol. 89, no. 1, p. 1051-1058.

WÜRSIG, B. and WÜRSIG, M., 1977. The photographic determination of group size, composition, and stability of coastal porpoises (Tursiops truncatus). Science, vol. 198, p. 755-756.

, 1979. Behaviour and ecology of the bottlenose dolphin, Tursiops truncatus, in the south Atlantic. Fishery Bulletin, vol. 77 , p. 399-412.

1980. Behavior and ecology of the dusky dolphin, Lagenorhynchus obscurus, in the south Atlantic. Fishery Bulletin, vol. 77, p. 871-890.

ZANELATTO, RC., 2001. Dieta do boto-cinza, Sotalia fluviatilis (CETACEA, DELPHINIDAE), no complexo estuarino da baía de Paranaguá e sua relação com a ictiofauna estuarina. Curitiba, PR: Universidade Federal do Paraná. 84 p. [Masters Dissertation]

ZAR, JH., 1996. Biostatistical Analysis. Englewood Cliffs, New Jersey: Prentice Hall. 